\title{
miR-375 mediates CRH signaling pathway in inhibiting E2 synthesis in porcine ovary
}

\author{
Chulin Yu*, Meiling Li*, Yue Wang, Ying Liu, Chengzhi Yan, Jirong Pan, Jiali Liu \\ and Sheng Cui \\ State Key Laboratory of Agrobiotechnology, College of Biological Sciences, China Agricultural University, \\ Beijing, People's Republic of China \\ Correspondence should be addressed to S Cui; Email: cuisheng@cau.edu.cn
}

*(C Yu and M Li contributed equally to this work)

\begin{abstract}
The corticotropin-releasing hormone (CRH) signaling system is involved in numbers of stress-related physiological and pathological responses, including its inhibiting effects on estradiol (E2) synthesis and follicular development in the ovary. In addition, there are reports that microRNAs (miRNAs) can control the function of animal reproductive system. The aim of present study was to investigate the functions of miR-375 and the relationship between miR-375 and CRH signaling molecules in the porcine ovary. First, our common PCR results show that miR-375 and the CRH receptor 1 (CRHR1) are expressed in porcine ovary, whereas CRH receptor 2 (CRHR2) is not detected. We further have located the cell types of miR-375 and CRHR1 by in situ hybridization (ISH), and the results show that miR-375 is located only in the granulosa cells, whereas CRHR1 is positive in all of granulosa cells and oocytes, inferring that miR-375 and CRHR1 are co-localized in granulosa cells. Second, we show that overexpression of miR-375 in cultured granulosa cells suppresses the E2 production, whereas miR-375 knockdown demonstrates the opposite result. Besides, our in vitro results demonstrate that miR-375 mediates the signaling pathway of CRH inhibiting E2 synthesis. Finally, our data show that the action of miR-375 is accomplished by directly binding to the 3'UTR of specificity protein1 (SP1) mRNA to decrease the SP1 protein level. Thus, we conclude that miR-375 is a key factor in regulating E2 synthesis by mediating the CRH signaling pathway.

Reproduction (2017) 153 63-73
\end{abstract}

\section{Introduction}

$\mathrm{CRH}$ is a 41 amino acid neuropeptide associated with stress response, and it is secreted mainly by the hypothalamus. The main function of $\mathrm{CRH}$ is to stimulate the release of adrenocorticotropic hormone (ACTH) in the pituitary, which in turn enhances the synthesis and secretion of cortisol in the adrenal gland. There are reports that $\mathrm{CRH}$ also performs functions in nervous system (Chen et al. 2005a, 2014), immune system (Karalis et al. 1991, Crofford et al. 1992), metabolic system (Carlin et al. 2006, Huising et al. 2010, Stengel \& Tache 2014) and reproduction system (Polkowska \& Przekop 1997, Erden et al. 1998). It is documented that $\mathrm{CRH}$ and its receptors have been detected in testis (Yoon et al. 1988), the ovary (Mastorakos et al. 1993) and the uterus (Makrigiannakis et al. 1995, Zoumakis et al. 1996), which suggests that $\mathrm{CRH}$ could directly affect the gonadal functions, including the development of germ cells and steroidogenesis in both male and female gonads (Ulisse et al. 1989, Ghizzoni et al. 1997, Kiapekou et al. 2011, Dinopoulou et al. 2013). However, the mechanism of $\mathrm{CRH}$ affecting steroidogenesis remains unclear.
It is known that $\mathrm{CRH}$ functions by activation of its two known receptors, including CRHR1 and CRHR2, which are typical G-protein-coupled receptors (GPCR) containing seven transmembrane domains. The binding of $\mathrm{CRH}$ to the CRHRs stimulates adenylyl cyclase, increases intracellular CAMP and calcium levels and activates protein kinase-A (Spiess et al. 1998), which subsequently activates MAP kinase in most of the $\mathrm{CRH}$ targeting cell types. In addition, it has been reported that miRNAs, such as miR-34 (Haramati et al. 2011), miR449a (Nemoto et al. 2013) and miR-375 (Zhang et al. 2013), may modulate cell responsiveness to CRH, and the related mechanisms are under extensive study.

miRNAs are non-coding RNAs containing 20-22 nucleotides, which reduce mRNA stability and block mRNA translation through fully or partially complementary sequence with mRNA 3'UTR (Landgraf et al. 2007). Previous studies have shown that miRNAs serve important roles in regulating ovary functions, such as, follicular development (Sen et al. 2014), cell proliferation and apoptosis (Sirotkin et al. 2010), and steroid hormone synthesis (Sirotkin et al. 2009). One such miRNA, miR-21, blocks periovulatory granulosa 
cell apoptosis by decreasing cleaved caspase3 (Carletti et al. 2010). miR-378 negatively regulates E2 synthesis by targeting aromatase in granulosa cells (Xu et al. 2011), and miR-375 is expressed in developmental stages of follicles, suggesting an important role in the follicular growth or ovulation mechanism (Kang et al. 2013). However, the functions of miR-375 in the ovary are still unknown. In addition, our previous studies have shown that miR-375 is involved in the CRH signaling pathway, depressing proopiomelanocortin (POMC) mRNA and protein levels in the mouse pituitary (Zhang et al. 2013). With this in mind, we hypothesize that there are some interactions or crosstalk between miR-375 and CRH signaling molecules in the ovary, which are crucial for our understanding the role of miR-375 affecting animal reproduction.

The present study was thus designed to investigate the miR-375 expression, functions and relationship to the $\mathrm{CRH}$ signaling pathway in the ovaries of pigs, which are an important farm animal and potential animal models for the related human medical research. Our results show that miR-375 is stimulated by CRH signaling and acts as a major mediator in inhibiting E2 synthesis by targeting $S P 1$. These findings provide further insight into the roles and mechanisms of $\mathrm{CRH}$ functions in steroid hormone synthesis and provide molecular targets for exploring methods of treatment for steroid-dependent reproductive disorders.

\section{Materials and methods}

\section{Animals}

The in vivo experiments of this study were carried out by using 8 adult female pigs, randomly divided into the experimental group $(n=4)$ and controls $(n=4)$. Intravenous injections of $0.9 \% \mathrm{NaCl}$ were administered to the controls, and injections of $50 \mu \mathrm{g} \mathrm{CRH} \mathrm{(1151;} \mathrm{TOCRIS,} \mathrm{Minneapolis,} \mathrm{MI,} \mathrm{USA)} \mathrm{were}$ administered to the experimental group (Salak-Johnson et al. 2004). Two hours after injection, the pigs were killed, and the blood and ovary samples were collected. The protocols pertaining to animal experiments, as we apply to this study, were approved by Chinese Animal Care and Use Committee of China Agricultural University.

\section{Tissue collection and cell culture}

The ovaries for the in vitro experiments were obtained from a local slaughterhouse and transported to the laboratory within $2 \mathrm{~h}$ of harvest and were maintained at $37^{\circ} \mathrm{C}$ in a sterile physiological saline solution $(0.9 \% \mathrm{NaCl}, 100 \mathrm{IU} / \mathrm{mL}$ penicillin, $100 \mathrm{IU} / \mathrm{mL}$ streptomycin). The collected tissues were then rinsed 3 times with physiological saline solution. For in situ hybridization, the collected porcine ovaries were fixed in $4 \%$ paraformaldehyde for $24 \mathrm{~h}$ and then placed in $30 \%$ sucrose overnight at $4{ }^{\circ} \mathrm{C}$. The tissues were embedded in Tissue Tek O.C.T. compound (4583, SAKURA, Torrance, CA, USA), and $10 \mu \mathrm{m}$ sections were cut. For the cell culture, the follicular fluid was aspirated from 3 to $5 \mathrm{~mm}$ follicles using a $20 \mathrm{~mL}$ syringe and centrifuged at $500 \mathrm{~g}$ for $5 \mathrm{~min}$ and granulosa cells (GCs) were then collected from the bottom of centrifuge tubes. The GCs were washed with serum-free DMEM/F12 (Invitrogen) culture medium for 3 times. The cells were then pipetted up and down several times to disperse the cells. Subsequently, cell viability was determined using Trypan blue dye (T6146, Sigma), and the cells were seeded with $1 \times 10^{5}$ per well in 12-well plates in $1 \mathrm{~mL}$ DMEM/F12 supplemented with $10 \%$ fetal bovine serum (Invitrogen). The cells were cultured in a highly humidified atmosphere of $95 \%$ air and $5 \% \mathrm{CO}_{2}$ at $37^{\circ} \mathrm{C}$. The porcine GCs were cultured in $10 \%$ fetal calf serumDMEM/F12 for $72 \mathrm{~h}$ before further treatment, and culture medium was refreshed each $24 \mathrm{~h}$.

\section{Plasmids construction and luciferase reporter assay}

The $160 \mathrm{bp}$ region of the SP1 gene 3'UTR from $1139 \mathrm{bp}$ to $1499 \mathrm{bp}$ and Liver Receptor Homolog-1 (LHR1) gene 3'UTR from $237 \mathrm{bp}$ to $397 \mathrm{bp} 3$ 'UTR sequences were cloned by overlap PCR. The sequences were constructed into the psiCHECK-2 vector (Promega) between the Xhol and Notl sites, and mutant 3'UTR of SP1 and LHR1 were also inserted as negative controls. All plasmids were transfected into the $293 \mathrm{~T}$ cells for $24 \mathrm{~h}$, and luciferase activity was analyzed by using dual-luciferase reporter assay kit (E1910; Promega) on a Modulus II Microplate Multimode Reader (Turner Biosystems, Sunnyvale, CA, USA) in accordance with the manufacturer's recommendations.

\section{Transient transfection}

The miR-375 mimic (forward, 5'-UUUGUUCGUUCGGCU CGCGUGA-3'; reverse, 5'-ACGCGAGCCGAACGAACAAA UU-3') and miR-375 inhibitor (5'-UCACGCGAGCCGAA CGAACAAA-3') were purchased from RiboBio (Guangzhou, China). The nc mimic (nc-mi) (forward, 5'-UUCUCCGAACG UGUCACGUTT-3' and reverse, 5'-ACGUGACACGUUCGG AGAATT-3') and nc inhibitor (nc-in) (5'-CAGUACUUUUGU GUAGUACAA-3') were used as negative control. The SP1 siRNA sequence (5'-GCAGCUACCUUGACUCCUATT-3') and the nc sequence (5'-UUCUUCGAACGUGUCACGUTT-3') were synthesized from GenePharma (Shanghai, China). The expression vector for SP1 (pEGFP-SP1 plasmid) was bought from Addgene (Cambridge, MA, USA) (Shen et al. 2009).

Transient transfections were conducted by using Lipofectamine 2000 Reagent (Invitrogen) in accordance with the manufacturer's recommendations. All transfection experiments were conducted at least three times.

\section{Radioimmunoassay (RIA)}

The porcine GCs culture medium was replaced by serumfree DMEM/F12 for $12 \mathrm{~h}$, followed by the addition of different concentrations of CRH (1151; TOCRIS) for $12 \mathrm{~h}$ before harvest. $\mathrm{E} 2$ and P4 levels in the culture medium were measured using RIA reagent purchased from the Beijing North Institute of Biological Technology (Beijing, China). The RIA was performed following the manufacturer's recommendations. The minimum 
detectable concentration of $\mathrm{E} 2$ was $2 \mathrm{pg} / \mathrm{mL}$ and $0.2 \mathrm{ng} / \mathrm{mL}$ for P4.

\section{Western blot}

Protein samples extracted from the cultured cells were subjected to $12 \%$ SDS-PAGE and immunoblotted as described previously (Li et al. 2014). For SP1 analysis, the membranes were incubated with rabbit anti-SP1 antibodies (1:200; BOSTER, Wuhan, China) and mouse anti-GAPDH antibodies (1:10,000; Ambion) overnight at $4^{\circ} \mathrm{C}$. The membranes were washed in Tris-buffered saline with $0.1 \%$ Tween-20 (TBST) for $30 \mathrm{~min}$ and TBST was changed every $10 \mathrm{~min}$, and then the membranes were incubated with alkaline phosphataseconjugated goat anti-rabbit or goat anti-mouse antibodies (1:5000; Zymed Laboratories, Carlsbad, CA, USA) at room temperature for $2 \mathrm{~h}$. After being washed in TBST for $30 \mathrm{~min}$, the membranes were exposed to nitrotetrazolium Blue chloride (NBT)/5-bromo-4-chloro-3-indolylphosphate p-toluidine salt (BCIP) until desired signals were achieved. We used the Image $2 x$ Software to assay the relative intensity of each blot. The intensity values of each group were normalized to GAPDH (internal control) in the same group.

\section{Common PCR and Real-time quantitative PCR (RT-qPCR)}

Total RNA was extracted from the cultured cells by RNAiso Plus (9109; TaKaRa), and then $1 \mu \mathrm{g}$ purified RNA was used for cDNA synthesis by Reverse Transcriptase M-MLV reagent (M170A; Promega). Reverse transcription was performed as its manufacturer's protocol. No-template control was included in all reverse transcription. The miRNA expression was analyzed by the method described previously (Chen et al. 2005b). RT-qPCR was carried out by SYBR premix Ex Taq (DRR420A; TaKaRa) in the ABI 7500 Real-time PCR system (Applied Biosystems). PCR conditions were as follows: $95^{\circ} \mathrm{C}$ for $10 \mathrm{~min}$; $95^{\circ} \mathrm{C}$ for $15 \mathrm{~s}$ and $60^{\circ} \mathrm{C}$ for $1 \mathrm{~min}$ (40 cycles). Relative RNA quantifications were normalized to endogenous control GAPDH. The primer sequences are shown in Table 1.

CRHRs and miR-375 expression were detected by common PCR using the primer sequences shown in Table 1. And the common PCR (Bio-Rad Laboratories) was performed using the following protocol: $95^{\circ} \mathrm{C}$ for $5 \mathrm{~min} ; 95^{\circ} \mathrm{C}$ for $30 \mathrm{~s}, 60^{\circ} \mathrm{C}$ for $30 \mathrm{~s}, 72^{\circ} \mathrm{C}$ for $30 \mathrm{~s}$ (35 cycles); $72^{\circ} \mathrm{C}$ for $5 \mathrm{~min} ; 4^{\circ} \mathrm{C}$ holding. PCR products were observed on a $2 \%$ agarose gel.

\section{In situ hybridization (ISH)}

A digoxigenin-labeled locked nucleic acid (LNA) probe (3818105; Exiqon, Woburn, MA, USA) was applied to miR-375 ISH. The CRHR1 ISH probe was 486 bp cRNA generated by DIG RNA Labeling Kit (11175025910; Roche Applied Science). The ISH was performed as described previously (Birnbacher et al. 1998, Javelle \& Timmermans 2012). The samples were fixed for $10 \mathrm{~min}$ in $4 \%$ paraformaldehyde and treated with $5 \mu \mathrm{g} / \mathrm{mL}$ proteinase $\mathrm{K}$ for $5 \mathrm{~min}$, followed by acetylation for $10 \mathrm{~min}$. The sections were pre-hybridized at room temperature for $4 \mathrm{~h}$, and then miR-375 and CRHR1 were hybridized at $57^{\circ} \mathrm{C}$ and $65^{\circ} \mathrm{C}$
Table 1 Primer names and sequences.

\begin{tabular}{|c|c|}
\hline Primer names & Sequence \\
\hline \multicolumn{2}{|l|}{ U6 } \\
\hline RT primer & AACGCTTCACGAATTTGCGT \\
\hline Sense & CTCGCTTCGGCAGCACA \\
\hline Antisense & AACGCTTCACGAATTTGCGT \\
\hline \multicolumn{2}{|l|}{ miR-375 } \\
\hline RT primer & $\begin{array}{l}\text { СTCAACTGGTGTCGTGGAGTCGGCAATTCGTTGA } \\
\text { GAGCGСАСТ }\end{array}$ \\
\hline Sense & ACAGAGATTTGTTCGTTCGGC \\
\hline Antisense & CTCAACTGGTGTCGTGGAGTC \\
\hline \multicolumn{2}{|l|}{ Pri-miR-375 } \\
\hline Sense & СТСТССGACСCGTATGGC \\
\hline Antisense & CGTTTTGTTCGTTCGGCTCG \\
\hline \multicolumn{2}{|l|}{ CRHR1 } \\
\hline Sense & ААСТССАТСТССGССТСС \\
\hline Antisense & GCCGTTGTTTGTGGTATTGT \\
\hline \multicolumn{2}{|l|}{ CRHR2 } \\
\hline Sense & TCTTGGACGGTTGGG \\
\hline Antisense & CATTCTCGGTAGGCATT \\
\hline \multicolumn{2}{|r|}{ 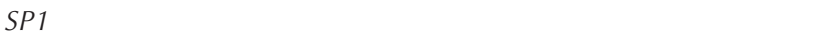 } \\
\hline Sense & GACAGTGGGGCAGGTT \\
\hline Antisense & GCAAGACGGGCAATAC \\
\hline \multicolumn{2}{|l|}{ GAPDH } \\
\hline Sense & GGTGAAGGTCGGAGTGAACG \\
\hline Antisense & CCTTGACTGTGCCGTGGAAT \\
\hline \multicolumn{2}{|l|}{ CYP19A1 } \\
\hline Sense & GTGACCGTCTGTGCCG \\
\hline Antisense & CCCCAGGAAGAGGTTGTTA \\
\hline \multicolumn{2}{|l|}{ CYP11A1 } \\
\hline Sense & GAACACGGAGGTAATGG \\
\hline Antisense & AGGCGAAGCGAAACA \\
\hline \multicolumn{2}{|l|}{$H S D 3 B$} \\
\hline Sense & CGССТGCGAAGAAGA \\
\hline Antisense & AGAGCCCAGCCGTTA \\
\hline \multicolumn{2}{|l|}{$H S D 17 B$} \\
\hline Sense & AGAGTCTGGCGGTTGTG \\
\hline Antisense & GCGGGAGAAGAGGTCA \\
\hline
\end{tabular}

overnight. The signal was detected by an alkaline phosphataseconjugated anti-DIG antibody (11093274910; Roche). The sections were incubated in NBT/BCIP at $4^{\circ} \mathrm{C}$ for several hours until the desired signal was achieved and then photographed under a microscope (IX71, Olympus).

\section{MicroRNA target prediction}

The two computational prediction algorithms used were miRanda (www.microrna.org) and pictar (pictar.mdc-berlin. de), and human SP1 and LHR1 were predicted to be the targets of miR-375. Notably, the predicted miR-375 target sites in both SP1 and LHR 1 were conserved by homology comparison. Subsequently, we used the RNAhybrid to predict the minimum free energy of hybridization between miR-375 and its putative target genes.

\section{Statistical analysis}

Statistical analysis in this study was conducted using GraphPad Prism 6.0. Two group comparisons were performed by Student's $t$-test. More than two groups were compared using a one-way analysis of variance (ANOVA) followed by Student's $t$-test. All experiments were independently conducted for at least three times. All values were expressed as means \pm S.E.M. $P<0.05$ was considered significant. 


\section{Results}

\section{Expressions of miR-375 and CRHRs in the porcine ovary}

To investigate the functional relationship between miR-375 expression and the CRH signaling pathway in the porcine ovary, we initially examined the expressions of miR-375, CRH receptors, including CRHR1 and CRHR2, in the porcine ovary by common PCR. The results showed that miR-375 and CRHR1 were expressed in the porcine ovary, whereas CRHR2 was not detected (Fig. 1A, C). Further, we located the CRHR1 and miR-375 by ISH, and the results showed that miR-375 was located only in the granulosa cells (Fig. 1B), whereas CRHR1 was positive in all the granulosa cells and oocytes (Fig. 1D). These results indicate that miR-375 and CRHR1 are co-expressed in porcine granulosa cells and suggest that miR-375 is potentially involved in the regulating effects of $\mathrm{CRH}$ on porcine granulosa cells.

\section{Both miR-375 and CRH negatively regulate E2 synthesis}

To determine the effects of miR-375 on porcine granulosa cells, miR-375 was over-expressed and knocked down by transfecting the miR-375 mimic and inhibitor respectively. The results showed that the miR-375 mimic increased miR-375 level by many thousands of times, and the miR-375 inhibitor decreased the miR-375 level by $\sim 66 \%$ compared with the control, but had no effect on miR-125b and
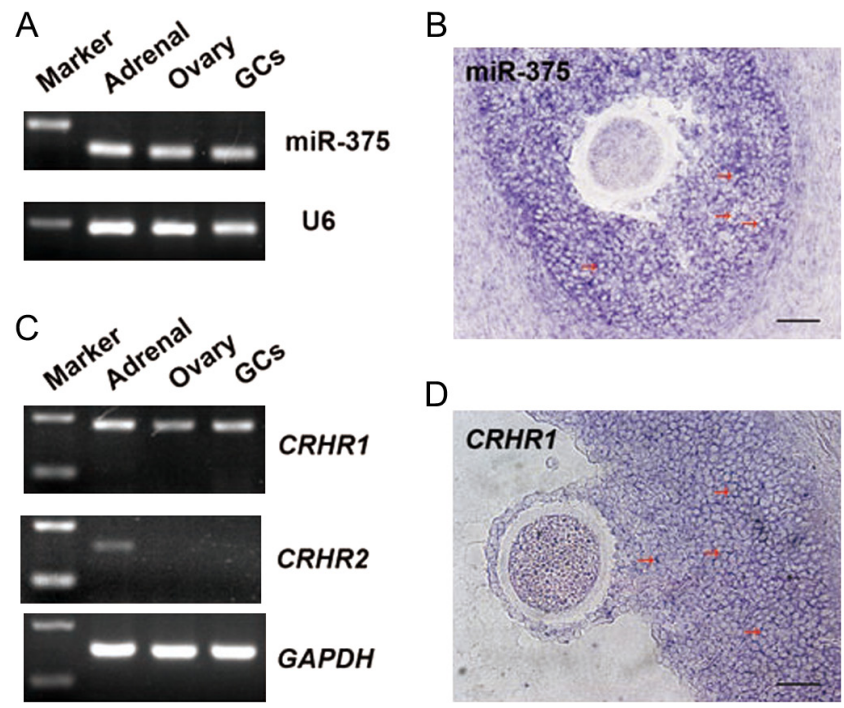

D

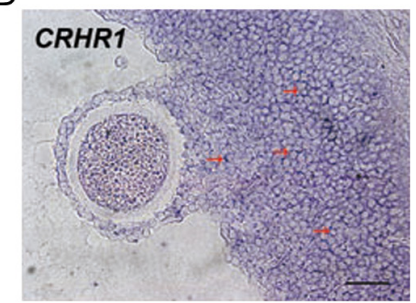

Figure 1 Expressions of miR-375 and CRHRs in the porcine ovary. (A) miR-375 expression was examined by common PCR (U6 small nuclear RNA amplified as internal reference) in the porcine ovary and granulosa cells (GCs), and adrenal is positive control.

(B) miR-375 expression was located by ISH in the porcine ovary. (C) CRHR1 and CRHR2 were detected in the porcine ovary and granulosa cells (GCs) by common PCR. (D) CRHR1 was localized in the porcine ovary by ISH. Scale bar is $50 \mu \mathrm{m}$.
miR-143 expression (Fig. 2A, B). As the production of $\mathrm{E} 2$ and $\mathrm{P} 4$ are the important functions of the granulosa cells, we assayed the effects of the miR-375 mimic and inhibitor on E2 and P4 levels. The RIA results revealed that the miR-375 mimic decreased E2 level in the culture medium by $\sim 47 \%$ (Fig. 2C), whereas the miR-375 inhibitor increased E2 level 1.4 times. However, it was out of our expectation that neither the miR-375 mimic nor inhibitor would have significant effects on P4 level (Fig. 2D). These results suggest that miR-375 specifically inhibits E2 synthesis in porcine granulosa cells. Further, we assayed the expressions of the related enzymes that are required for E2 synthesis, including 17 beta-hydroxysteroid dehydrogenase (HSD17B) and CYP19A1, 3 beta-hydroxysteroid dehydrogenase (HSD3B), cytochrome P450 family 11 subfamily A member 1 (CYP11A1) by RT-qPCR. The results showed that miR-375 overexpression inhibited the CYP19A1 mRNA level by $\sim 37 \%$, but it increased $\sim 1.9$ times when miR-375 was knocked down. However, neither the miR-375 mimic nor the miR-375 inhibitor had significant effects on $H S D 17 B$, HSD3B or CYP11A1 expression (Fig. 2E, F). These results indicate that miR-375 negatively regulates E2 synthesis by affecting CYP19A1 expression in porcine granulosa cells.

It is thought that $\mathrm{CRH}$ has negative effects on ovary steroidogenesis (Calogero et al. 1996, Dinopoulou et al. 2013). To confirm the CRH functions in porcine granulosa cells, the cultured cells were treated with $\mathrm{CRH}$ for $12 \mathrm{~h}$. The results showed that $100 \mathrm{nM} \mathrm{CRH}$ decreased E2 level by $42 \%$ in the culture medium. Further, we administrated $50 \mu \mathrm{g} \mathrm{CRH}$ to the adult pigs for $2 \mathrm{~h}$ (SalakJohnson et al. 2004), and were then assayed to know the effects of CRH on E2 synthesis. The results showed that the $\mathrm{CRH}$ decreased global E2 concentration by $25 \%$ in vivo (Fig. 2G, J). We also examined the related enzyme expression. The RT-qPCR results showed that CYP19A1 mRNA were decreased after CRH treatment both in vitro and in vivo, whereas the $C R H$ had no obvious effect on the expressions of HSD17B, HSD3B and CYP11A1 (Fig. 2H, $\mathrm{K})$. Besides, our Western blot results demonstrated that the protein level of CYP19A1 was decreased after CRH treatment both in vitro and in vivo (Fig. 2l, L). These data demonstrate that both miR-375 and CRH play negative roles in E2 synthesis in the porcine ovary.

\section{CRH upregulates miR-375 expression via PKA-p38 MAPK signaling pathway}

To examine whether $\mathrm{CRH}$ signaling affects miR-375 expression in porcine granulosa cells, cultured cells were treated with $0,0.1,1,10$ and $100 \mathrm{nM} \mathrm{CRH}$ for $12 \mathrm{~h}$ (Ghizzoni et al. 1997). The results showed that $100 \mathrm{nM}$ $\mathrm{CRH}$ increased Pri-miR-375 and miR-375 expression in cultured cells by $\sim 3$ times (Fig. 3A, B). Further, to confirm the physiological significance of $\mathrm{CRH}$ and 
A

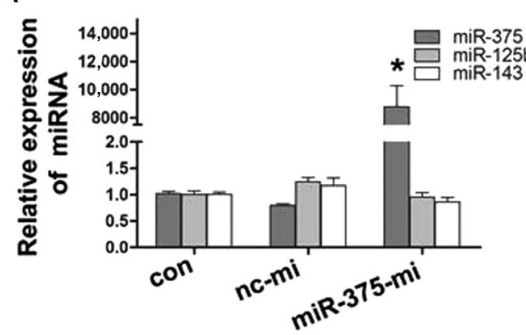

D

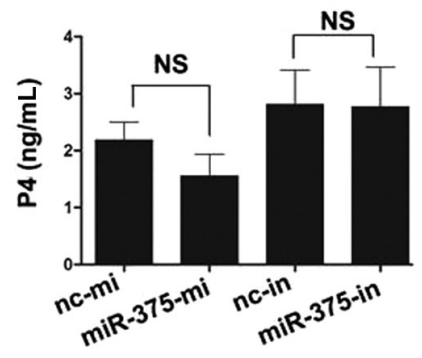

G

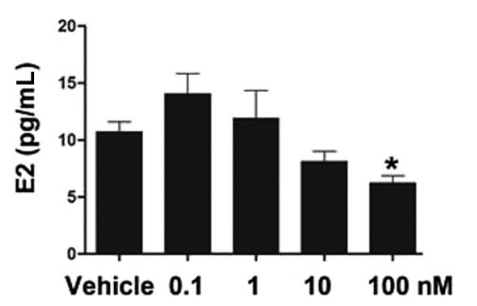

$J$

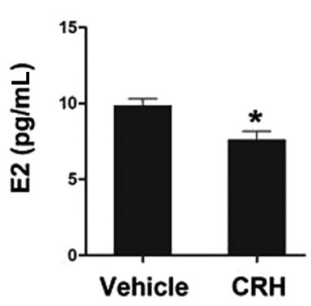

B

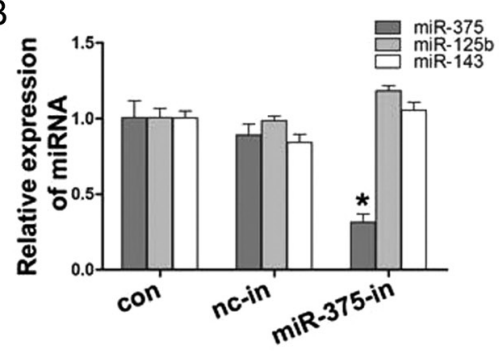

E

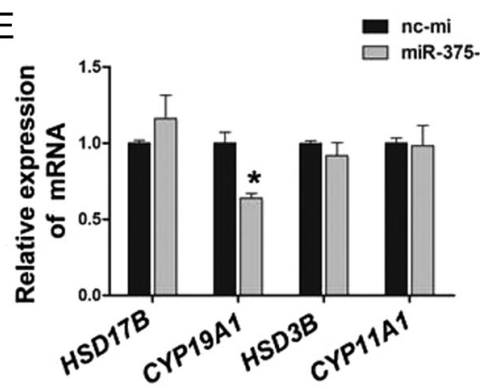

$\mathrm{H}$

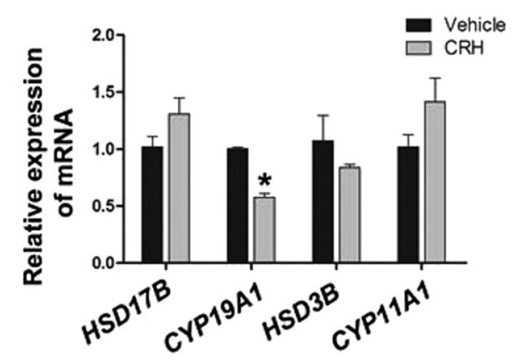

K

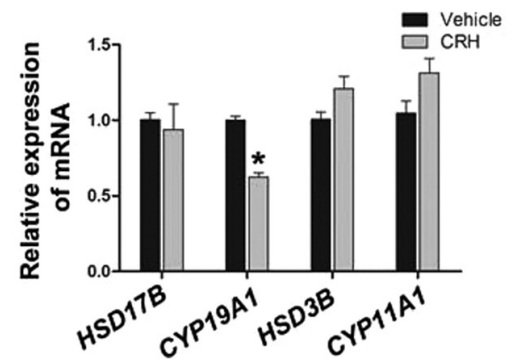

C

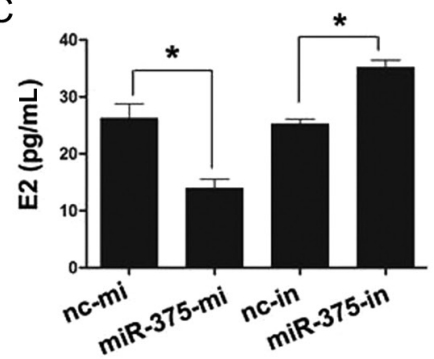

F

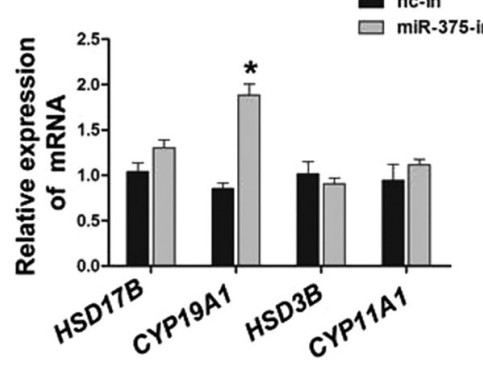

I

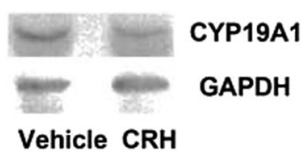

L

Figure 2 Effect of miR-375 on steroid hormone synthesis in cultured porcine granulosa cells. (A and B) Quantification of intracellular miR-375, the miR-125b, and the miR-143 levels were assayed by RT-qPCR after the cultured granulosa cells transfected with the miR-375 mimic (miR-375-mi) (A) and miR-375 inhibitor (miR-375-in) (B) for 24h. Con was non-transfection control. The versus cells were transfected with nc mimic (nc-mi) and nc inhibitor (nc-in) as negative control. (C and D), E2 (C) and P4 levels (D) in the culture medium were assayed by RIA after transfected with the miR-375 mimic or inhibitor for $24 \mathrm{~h}$. (E and F) Quantification of intracellular HSD17B, CYP19A1, HSD3B and CYP11A1 mRNA expressions were analyzed by RT-qPCR after the cultured cells transfected with the miR-375 mimic (E) or inhibitor (F) for $24 \mathrm{~h}$. (G) E2 levels in the culture medium were measured by RIA after the cultured granulosa cells exposed to $0,0.1,1,10$ and $100 \mathrm{nM} \mathrm{CRH}$ for $12 \mathrm{~h}$. ( $\mathrm{H}$ ) Quantification of intracellular HSD17B, CYP19A1, HSD3B and CYP11A1 mRNA levels were analyzed by RT-qPCR after the cultured granulosa cells were exposed to $100 \mathrm{nM}$ CRH for $12 \mathrm{~h}$. (I) The CYP19A1 protein levels were examined by Western blot after the cultured granulosa cells were exposed to $100 \mathrm{nM}$ CRH for $12 \mathrm{~h}$. (J, K and L) After the pigs injection with CRH for $2 \mathrm{~h}, \mathrm{E} 2$ levels in serum were assayed by RIA (J), HSD17B, CYP19A1, HSD3B and CYP11A1 mRNA were assayed by RT-qPCR (K), and CYP19A1 protein levels were analyzed by Western blot (L). Data are as shown as means \pm S.E.M. $(n=4)$. Significance differences are indicated by $* P<0.05$, and NS means not significant $(t$ test).

miR-375, the in vivo results showed that the $\mathrm{CRH}$ increased the ovary Pri-miR-375 and miR-375 levels by $\sim 3$ times (Fig. 3C, D), consistent with the in vitro results.
To determine the signaling pathway involved in $\mathrm{CRH}$ upregulating miR-375 expression, we pre-incubated the cultured cells with the inhibitors of the reported key 

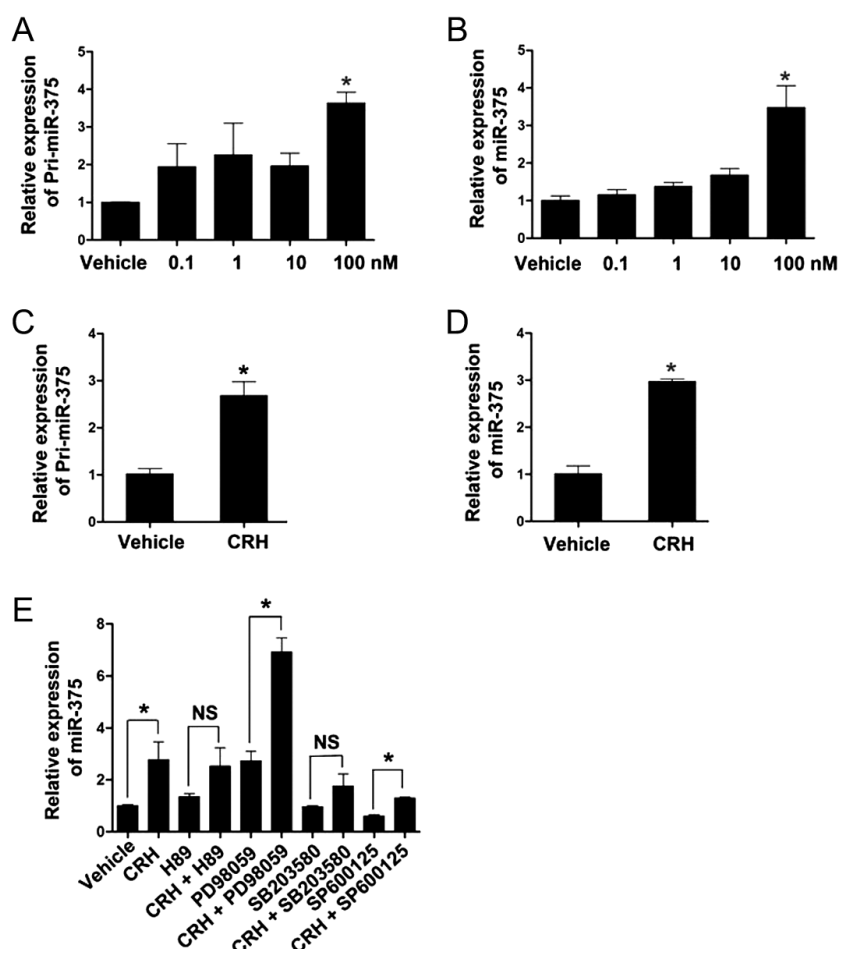

Figure 3 MiR-375 is enhanced by $\mathrm{CRH}$ both in vitro and in vivo. (A and B) Quantification of intracellular Pri-miR-375 and miR-375 levels were analyzed by RT-qPCR after the cultured granulosa cells exposed to $0,0.1,1,10$ and $100 \mathrm{nM}$ CRH for $12 \mathrm{~h}$ respectively. (C and D) Quantification of intracellular Pri-miR-375 and miR-375 levels were analyzed by RT-qPCR after the pigs injection with $\mathrm{CRH}$ for $2 \mathrm{~h}$. (E) After several signal pathway inhibitors including $20 \mu \mathrm{M}$ of H89 (PKA), PD98059 (ERK), SB203580 (p38 MAPK) and SP600125 (JNK) (final concentration $20 \mu \mathrm{M}$ ) and $100 \mathrm{nM}$ CRH treatment for $12 \mathrm{~h}$, intracellular miR-375 levels in the granulosa cells were assayed by RT-qPCR. Data are as shown as means \pm S.E.M. $(n=3)$. Significant differences are indicated by $* P<0.05$ and NS means not significant ( $t$ test).

downstream molecules of the $\mathrm{CRH}$ signaling pathways (Dermitzaki et al. 2002, Park et al. 2005, Cao et al. 2006), including $20 \mu \mathrm{M}$ of H89 (PKA), PD98059 (ERK), SB203580 (p38 MAPK) and SP600125 (JNK) for $1 \mathrm{~h}$ before $\mathrm{CRH}$ treatment. The results showed that only PKA inhibitor H89 and p38 MAPK inhibitor SB203580 blocked the stimulation of miR-375 expression by $\mathrm{CRH}$ (Fig. 3E). Further, we used different doses of H89, SB203580 and LY2228022 (p38 MAPK) to pre-treat the cultured cells for $1 \mathrm{~h}$ before $100 \mathrm{nM}$ CRH treatment. The results demonstrated that the inhibitors attenuate the effect of CRH-stimulating miR-375 expression, which showed dose-dependent effects. These data indicate that CRH enhances miR-375 expression through the PKA-p38 MAPK signaling pathway in porcine granulosa cells.

\section{MiR-375 mediates CRH negatively regulating E2 synthesis}

To find out whether miR-375 was involved in $\mathrm{CRH}$ regulating E2 synthesis, the cultured cells were transfected with the miR-375 mimic or inhibitor for $24 \mathrm{~h}$ before adding $100 \mathrm{nM}$ CRH for another $12 \mathrm{~h}$. The RIA results demonstrated that both the miR-375 mimic and $\mathrm{CRH}$ inhibited E2 levels (Fig. 4A), whereas these inhibitory effects of $\mathrm{CRH}$ were reversed by the miR-375 inhibitor (Fig. 4B). These data demonstrate that $\mathrm{CRH}$ inhibits E2 synthesis mainly through the miR-375 in porcine granulosa cells.

\section{SP1 is a direct target of miR-375 involved in CRH signaling pathway}

To determine the potential target of miR-375 affecting E2 synthesis in porcine granulosa cells, we used computational prediction algorithms, including miRanda and pictar. Among the putative target genes, SP1 and LHR1 play important roles in ovarian steroid hormone synthesis. Because the porcine SP1 sequence was not available on the NCBI website, we designed the primers for the porcine SP1 $3^{\prime} U T R$ region using the available human and mouse SP1 homologous sequences, and the PCR product was sequenced. The results showed that the miR-375binding site in SP1 3'UTR was conserved between human and pigs (Fig. 5A). Based on porcine SP1 and
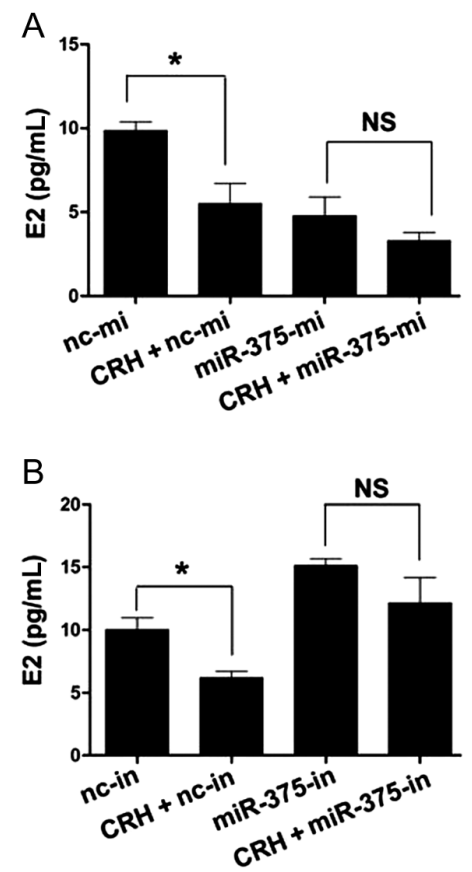

Figure 4 Effects of the miR-375 and CRH on E2 synthesis in the porcine granulosa cells. (A) E2 levels in the culture medium were assayed by RIA after the cells were transfected with the miR-375 mimic for $24 \mathrm{~h}$ and added $100 \mathrm{nM} \mathrm{CRH}$ for another $12 \mathrm{~h}$. (B) E2 levels in the culture medium were assayed by RIA after the cells were transfected with the miR-375 inhibitor for $24 \mathrm{~h}$ and added $100 \mathrm{nM}$ $\mathrm{CRH}$ for another $12 \mathrm{~h}$. Data are as shown as means \pm S.E.M. $(n=3)$. Significant differences are indicated by $* P<0.05$, and NS means not significant ( $t$ test). 
LHR1 3'UTR sequences, the putative miR-375-binding sites in SP1 and LHR1 3'UTR were predicted (Fig. 5B). Further, we used the RNAhybrid to predict the minimum free energy of hybridization between miR-375 and predicted targets (Fig. 5C). The putative targets' 3'UTR (wild type and mutant type) were then cloned into the psiCHECK-2 vector at downstream of the luciferase gene (Fig. 5D). The dual-luciferase reporter assay showed that the luciferase activity was suppressed by $\sim 30 \%$ in $293 \mathrm{~T}$ cells after co-transfecting with the miR-375 mimic and
A

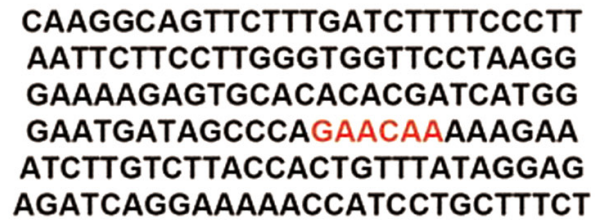

C

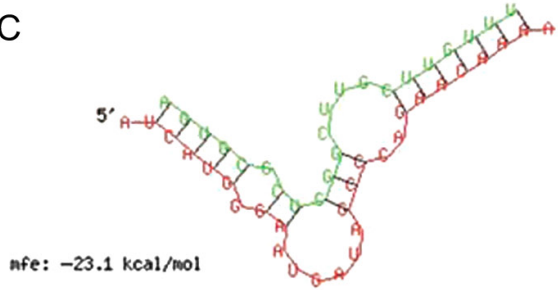

E

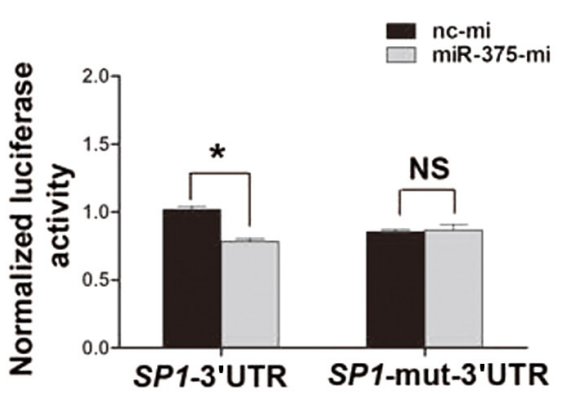

B

MiR-375----3'-AGUGCGCUCGGCUUGCUUGUUU-5'<smiles>C1=CC2C1C1C=CC2C2C=CC21</smiles>

Position 1430 of SP1 3'UTR----5'-GGGAAUGAUAGCCCAGAACAAA-3' Mutant SP1 3'UTR----5'-GGGAAUGAUAGCCCAATCAGTA-3'

MiR-375----3'-AGUGCGCUCGGCUUGCUUGUUU-5' || |

Position of 337 LHR1 3'UTR----5'-ACCAACGTGGCGCCAGAACAAA-3' Mutant LHR1 3'UTR----5'--ACCAACGTGGCGCCAATCAGTA-3'

D

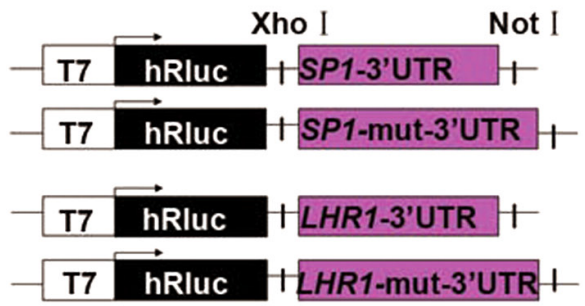

$\mathrm{F}$

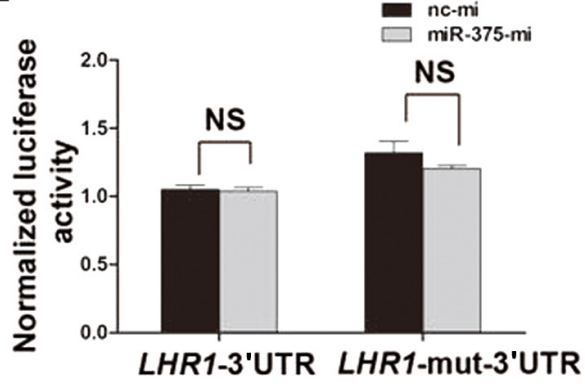

G

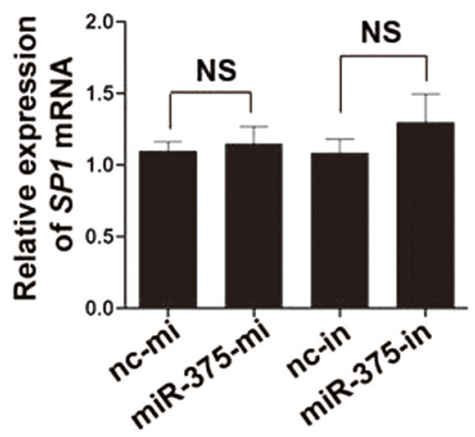

$\mathrm{H}$

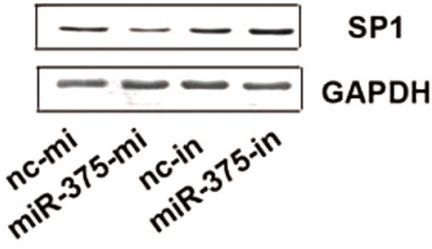

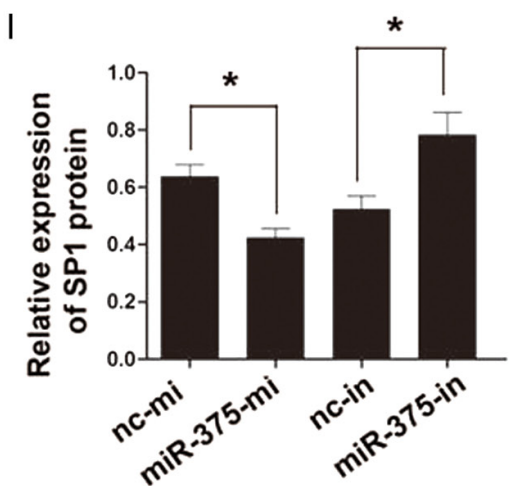

Figure 5 The direct target gene of miR-375 in the porcine granulosa cells. (A) The miR-375-binding site in SP1 mRNA 3'UTR of pigs. (B) The predicted miR-375 target sites of 3'UTR in SP1 and LHR1 mRNA, the seed sequence labeled as red. (C) The minimum free energy of hybridization between miR-375 and SP1 mRNA was predicted by the RNA hybrid. (D) Schematic representations of 3'UTR insert sites of target genes in the psiCHECK-2 vector. (E and F) The 293T cells were co-transfected with the miR-375 mimic and 3'UTR of putative targets (wild type or mutant) for $24 \mathrm{~h}$, and luciferase activities were measured by using dual-luciferase reporter assay kit. (G, H, I) Quantification of intracellular of SP1 mRNA and protein levels were respectively analyzed by RT-qPCR $(\mathrm{G})$ and Western blot $(\mathrm{H}, \mathrm{l})$ after the cells transfected with the miR-375 mimic or inhibitor for $24 \mathrm{~h}$. Data are as shown as means \pm S.E.M. $(n=4)$. Significant differences are indicated by $* P<0.05$, and NS means not significant ( $t$ test). 
A

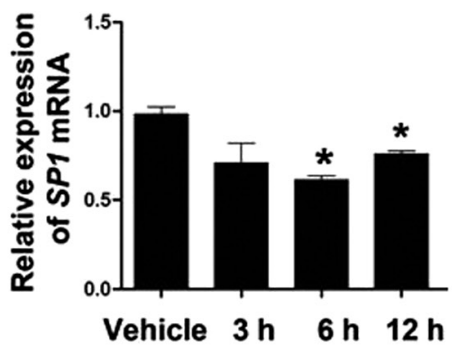

D

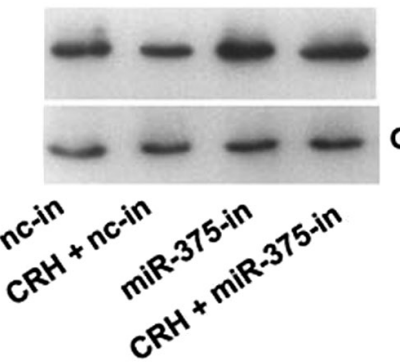

G

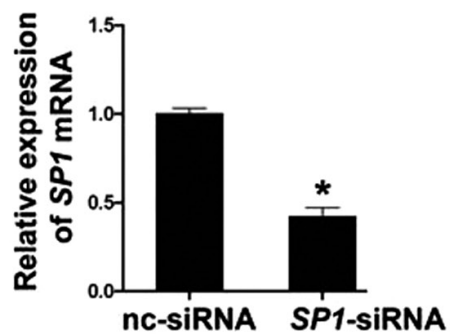

B

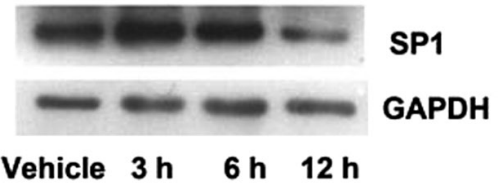

Vehicle $3 \mathrm{~h} \quad 6 \mathrm{~h} \quad 12 \mathrm{~h}$

E

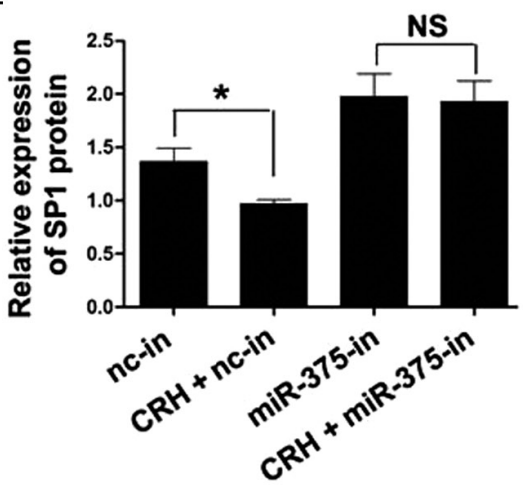

$\mathrm{H}$

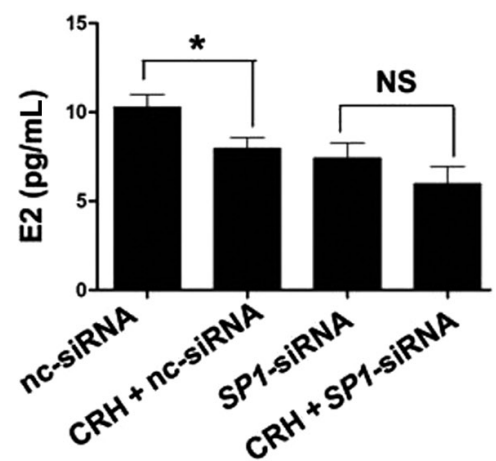

C

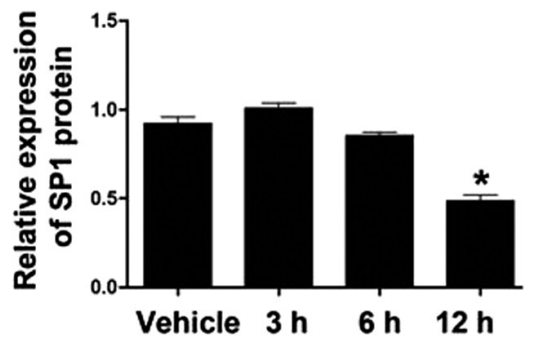

F

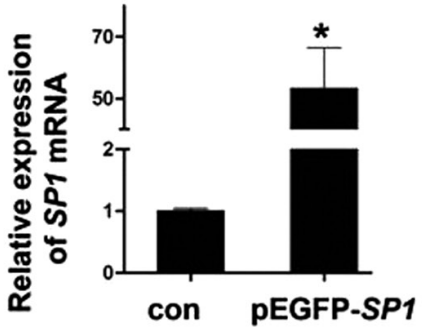

I

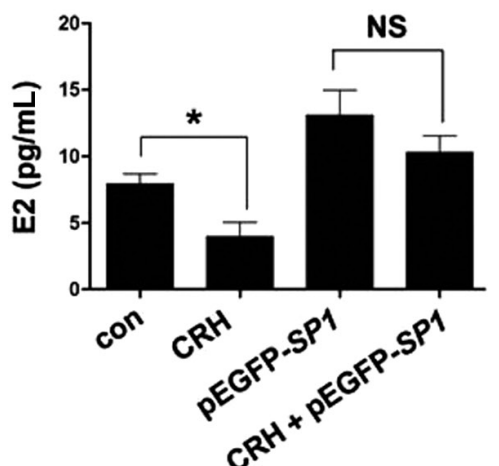

Figure 6 The functions of SP1 in regulating E2 synthesis affected by CRH. (A and B) Quantification of intracellular of SP1 mRNA (A) and protein level $(B, C)$ in cultured cells were assayed followed by $100 \mathrm{nM} C R H$ treating for $0,3,6$ and $12 \mathrm{~h}$ respectively. (D and E) The cultured cells were transfected with the miR-375 inhibitor for $24 \mathrm{~h}$ before $100 \mathrm{nM} \mathrm{CRH}$ treatment for $12 \mathrm{~h}$, and then the SP1 protein levels were examined by Western blot. ( $F$ and G) The SP1 mRNA levels were analyzed by RT-qPCR after the cells were transfected with SP1 siRNA and the pEGFP-SP1 plasmid for $24 \mathrm{~h}$. (H) E2 levels were examined after the SP1 siRNA transfection for $24 \mathrm{~h}$ and added with $100 \mathrm{nM}$ CRH for another $12 \mathrm{~h}$. (I) E2 levels were measured by RIA after the pEGFP-SP1 plasmid transfection for $24 \mathrm{~h}$ and added $100 \mathrm{nM} \mathrm{CRH}$ for another $12 \mathrm{~h}$. Data are as shown as means \pm S.E.M. $(n=3)$. Significant differences are indicated by $* P<0.05$, and NS means not significant $(t$ test).

p-Luc-SP1 3'UTR, comparing to the cells co-transfected with the miR-375 mimic and p-Luc-SP1 mutant 3'UTR (Fig. 5E); however, LHR1 showed no obvious differences (Fig. 5F). In addition, the Western blot results showed that miR-375 overexpression significantly decreased SP1 protein level and its knockdown significantly increased the SP1 protein level (Fig. $5 \mathrm{H}$ and I). However, either miR-375 overexpression or knockdown had no significant effect on SP1 mRNA level (Fig. 5G). These data indicate that $S P 1$ is a direct target of miR-375 involved in the CRH signaling pathway in porcine granulosa cells.

\section{SP1 is involved in CRH signaling pathway in regulating E2 synthesis}

To investigate whether SP1 acts as a signaling molecule in the $\mathrm{CRH}$ regulating E2 synthesis signaling pathway, the cultured cells were treated with $\mathrm{CRH}$ for $0,3,6$ and $12 \mathrm{~h}$ respectively. The RT-qPCR and Western blot results showed that both SP1 mRNA and protein levels were downregulated after $12 \mathrm{~h}$ CRH treatment (Fig. 6A, B, C). Further, the cultured cells were transfected with the miR375 inhibitor for $24 \mathrm{~h}$ before adding $100 \mathrm{nM} \mathrm{CRH}$ for another $12 \mathrm{~h}$, and the results showed miR-375 reversing 
the negative effect of $\mathrm{CRH}$ on SP1 protein (Fig. 6D, E). To confirm the functions of $S P 1$ ovarian steroidogenesis, $S P 1$ was respectively knocked down and over-expressed by transfecting SP1 siRNA and expression vector. The RT-qPCR results showed that the $S P 1$ expression vector significantly increased $S P 1$ mRNA level $\sim 1.5$ times and $S P 1$ siRNA decreased $S P 1$ expression by $\sim 60 \%$ (Fig. $6 \mathrm{~F}, \mathrm{G}$ ). Our results further showed that both $S P 1$ knockdown and $\mathrm{CRH}$ decreased E2 synthesis in the culture medium (Fig. $6 \mathrm{H}$ ), and the inhibitory effects of $\mathrm{CRH}$ on the E2 level were reversed by the overexpression of SP1 (Fig. 6I). These results demonstrate that $\mathrm{CRH}$ enhanced miR-375 and decreased E2 production through miR-375 by targeting SP1.

\section{Discussion}

miR-375 expression has been detected in the ovary (Kang et al. 2013), but its location and function in the porcine ovary have not been studied. Detection of miR375 in porcine ovary shows that miR-375 is localized in porcine granulosa cells, suggesting that miR-375 plays regulatory roles in steroid hormone production in granulosa cells. Our in vitro results further demonstrate that miR-375 negatively affects E2 production, which is involved in CRH signaling pathway. This evidence suggests that miR-375 mainly acts as an intermediator molecule in $\mathrm{CRH}$ regulation of E2 synthesis, but much more in vivo experiments are required to reveal how miR-375 affects reproductive functions.

The present study shows that miR-375 specifically decreases E2 synthesis in porcine granulosa cells but has no obvious influence on P4 levels. It is known that E2 plays key roles in female animal reproductive processes, which can be synthesized in granulosa cells. In support, our results here show that miR-375 only affects the expression of CYP19A1, the key enzyme of E2 synthesis. However, we still do not know the mechanisms of miR375's affecting CYP19A1 expression and E2 synthesis.

Dinopolou and coworkers (Dinopoulou et al. 2013) have reported that both Crhr1 and Crhr2 mRNA were detected in mouse preantral follicles, but the Crhr1 expression was significantly higher than that of Crhr2. Our results show that only CRHR 1 is expressed in the porcine ovary, whereas CRHR2 mRNA is not detected. These findings suggest that CRHR1 may be involved in a more important role in the regulation of ovarian functions. With regard to steroidogenesis, it is reported that $\mathrm{CRH}$ suppresses FSH-promoted E2 production in the rat granulosa cells at a concentration of $10 \mathrm{nM}$, whereas $0.1 \mathrm{nM}$ CRH significantly inhibits E2 release in the human granulosa-lutein cells (Calogero et al. 1996, 2002). And in our study, the results show that $100 \mathrm{nM}$ CRH inhibits CYP19A1 expression and E2 levels in the porcine ovary, which could be probably due to different animal species showing different sensibilities to $\mathrm{CRH}$.
The results presented here demonstrate that CRHR1 co-expresses with miR-375 in porcine granulosa cells. We infer that there is some crosstalk between miR375 and the $\mathrm{CRH}$ signaling pathway. Further, our data show that $\mathrm{CRH}$ upregulates endogenous expression of miR-375 both in vitro and in vivo. It is well known that miRNAs are processed from their long RNA transcript, namely primary miRNA (Pri-miRNA) (Nothnick 2012). Our results show that $\mathrm{CRH}$ could upregulate PrimiR-375 expression. These findings suggest that $\mathrm{CRH}$ stimulates miR-375 expression by enhancing PrimiR-375 transcription. It has been reported that PKAp38 is involved in the CRH signaling pathway in mast cells (Cao et al. 2006), keratinocytes (Park et al. 2005), PC12 cells (Dermitzaki et al. 2002) and these reports are consistent with the data presented here, although there are also reports suggesting that the binding of $\mathrm{CRH}$ to its receptors activates the PKA-ERK signaling pathway in pituitary (Kovalovsky et al. 2002). In addition, the present study demonstrates that miR-375 knockdown attenuates the negative effects of $\mathrm{CRH}$ on E2 synthesis and suggests that miR-375 acts as a downstream molecule of $\mathrm{CRH}$ affecting the E2 synthesis signaling pathway in granulosa cells. These data collectively indicate that miR-375 mediates the CRH-PKA-p38 MAPK signaling affecting E2 synthesis.

To find the target gene of miR-375, the SP1 and $L H R 1$ were predicted as potential targets through use

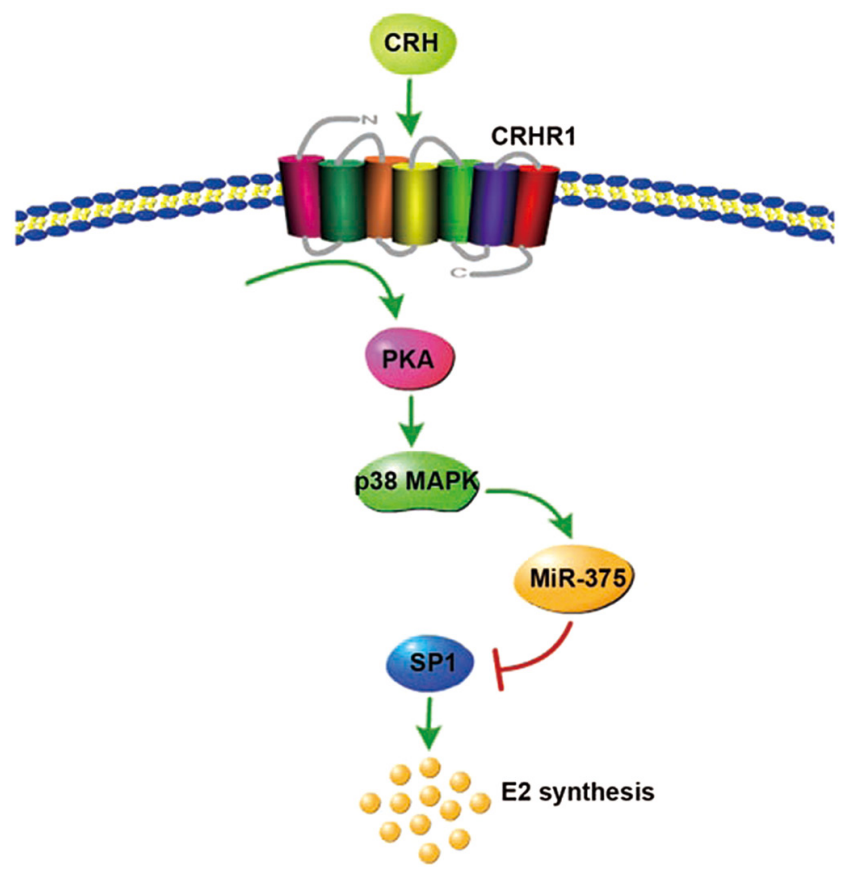

Figure 7 A schematic of miR-375 mediates the signaling pathway of CRH inhibiting E2 synthesis. CRH activates PKA-p38 signaling pathway by binding to CRHR1, which in turn enhances miR-375 expression. Our results have shown that miR-375 plays a negative role in E2 synthesis via its direct target gene SP1 in this pathway. Arrows mean stimulation and $\mathrm{T}$ bars indicate inhibition. 
of bioinformatics methods. The in vitro experiment results show that $S P 1$ is a direct target of miR-375 in the porcine ovary; these findings agree with the results in cervical SiHa and CaSki cells (Wang et al. 2011). Our results further show that SP1 overexpression promotes E2 synthesis and its knockdown inhibits E2 production in porcine granulosa cells. These results indicate that transcription factor SP1 performs a positive role in miR-375 regulating E2 synthesis in these cells. However, the mechanisms of SP1's promotion of E2 synthesis will require additional research. Further, we show that $100 \mathrm{nM}$ CRH downregulates both SP1 mRNA and protein levels in cultured granulosa cells, suggesting that SP1 is a downstream molecule involved in the $\mathrm{CRH}$ signaling pathway. Our study also shows that the miR-375 inhibitor could reverse the negative effects of $\mathrm{CRH}$ on SP1 protein levels and E2 synthesis in vitro. Taken together, these collective data suggest that $S P 1$ is a direct target of miR-375 in the $\mathrm{CRH}$ signaling pathway in porcine granulosa cells.

To conclude, the present study shows that miR-375 and CRHR 1 are expressed in porcine granulosa cells and that miR-375 plays a negative role in regulating the effect of $\mathrm{CRH}$ on E2 synthesis. In addition, we have shown that the signaling of $\mathrm{CRH}$ is transduced through CRHR1 and PKA-p38, subsequently enhancing primiR-375 and miR-375 expression, targeting SP1 and thus decreasing E2 synthesis in the porcine ovary (Fig. 7). As our study suggests, miR-375 serves as an important regulator in $\mathrm{E} 2$ synthesis by mediating the $\mathrm{CRH}$ signaling pathway in the porcine granulosa cells. These findings will help identify potential molecules for the treatment of reproductive disorders.

\section{Declaration of interest}

The authors declare that there is no conflict of interest that could be perceived as prejudicing the impartiality of the research reported.

\section{Funding}

This work was supported by the National Basic Research Program of China (2014CB138505 and 2013CB945503) and the Natural Science Foundation of China (3143000189 and 31372393).

\section{Acknowledgements}

The pEGFP-SP1 plasmid was acquired from the Department of Ophthalmology and Visual Sciences, University of Illinois College of Medicine, Chicago, IL, USA.

\section{References}

Birnbacher R, Amann G, Breitschopf H, Lassmann H, Suchanek G \& Heinz-Erian P 1998 Cellular localization of insulin-like growth factor II mRNA in the human fetus and the placenta: detection with a digoxigenin-labeled cRNA probe and immunocytochemistry. Pediatric Research 43 614-620. (doi:10.1203/00006450-199805000-00009)

Calogero AE, Burrello N, Negri-Cesi P, Papale L, Palumbo MA, Cianci A, Sanfilippo S \& D'Agata R 1996 Effects of corticotropin-releasing hormone on ovarian estrogen production in vitro. Endocrinology 137 4161-4166. (doi:10.1210/en.137.10.4161)

Calogero AE, Barreca A, Burrello N, Palermo I, Giordano G, D'Agata $R$ \& Vicari E 2002 Corticotrophin-releasing hormone inhibits insulin-like growth factor-I release from primary cultures of rat granulosa cells. Journal of Endocrinology 174 493-498. (doi:10.1677/joe.0.1740493)

Cao J, Cetrulo CL \& Theoharides TC 2006 Corticotropin-releasing hormone induces vascular endothelial growth factor release from human mast cells via the cAMP/protein kinase A/p38 mitogen-activated protein kinase pathway. Molecular Pharmacology 69 998-1006. (doi:10.1124/ mol.105.019539)

Carletti MZ, Fiedler SD \& Christenson LK 2010 MicroRNA 21 blocks apoptosis in mouse periovulatory granulosa cells. Biology of Reproduction 83 286-295. (doi:10.1095/biolreprod.109.081448)

Carlin KM, Vale WW \& Bale TL 2006 Vital functions of corticotropinreleasing factor (CRF) pathways in maintenance and regulation of energy homeostasis. PNAS 103 3462-3467. (doi:10.1073/pnas.0511320103)

Chen AM, Perrin MH, Digruccio MR, Vaughan JM, Brar BK, Arias CM, Lewis KA, Rivier JE, Sawchenko PE \& Vale WW 2005a A soluble mouse brain splice variant of type 2alpha corticotropin-releasing factor (CRF) receptor binds ligands and modulates their activity. PNAS 102 2620-2625. (doi:10.1073/pnas.0409583102)

Chen C, Ridzon DA, Broomer AJ, Zhou Z, Lee DH, Nguyen JT, Barbisin M, Xu NL, Mahuvakar VR, Andersen MR et al. 2005b Realtime quantification of microRNAs by stem-loop RT-PCR. Nucleic Acids Research 33 e179. (doi:10.1093/nar/gni178)

Chen SJ, Yang JF, Kong FP, Ren JL, Hao K, Li M, Yuan Y, Chen XC, Yu RS, Li JF et al. 2014 Overactivation of corticotropin-releasing factor receptor type 1 and aquaporin- 4 by hypoxia induces cerebral edema. PNAS 111 13199-13204. (doi:10.1073/pnas.1404493111)

Crofford LJ, Sano H, Karalis K, Webster EL, Goldmuntz EA, Chrousos GP \& Wilder RL 1992 Local secretion of corticotropin-releasing hormone in the joints of Lewis rats with inflammatory arthritis. Journal of Clinical Investigation 90 2555-2564. (doi:10.1172/JCI116150)

Dermitzaki E, Tsatsanis C, Gravanis A \& Margioris AN 2002 Corticotropinreleasing hormone induces Fas ligand production and apoptosis in PC12 cells via activation of p38 mitogen-activated protein kinase. Journal of Biological Chemistry 277 12280-12287. (doi:10.1074/jbc.M111236200)

Dinopoulou V, Partsinevelos GA, Mavrogianni D, Anagnostou E, Drakakis P, Makrigiannakis A, Chrousos GP \& Loutradis D 2013 The effect of $\mathrm{CRH}$ and its inhibitor, antalarmin, on in vitro growth of preantral mouse follicles, early embryo development, and steroidogenesis. Endocrinology 154 222-231. (doi:10.1210/en.2012-1838)

Erden HF, Zwain IH, Asakura H \& Yen SS 1998 Corticotropin-releasing factor inhibits luteinizing hormone-stimulated P450c17 gene expression and androgen production by isolated thecal cells of human ovarian follicles. Journal of Clinical Endocrinology and Metabolism 83 448-452. (doi:10.1210/jc.83.2.448)

Ghizzoni L, Mastorakos G, Vottero A, Barreca A, Furlini M, Cesarone A, Ferrari B, Chrousos GP \& Bernasconi S 1997 Corticotropin-releasing hormone $(\mathrm{CRH})$ inhibits steroid biosynthesis by cultured human granulosalutein cells in a CRH and interleukin-1 receptor-mediated fashion. Endocrinology 138 4806-4811. (doi:10.1210/endo.138.11.5474)

Haramati S, Navon I, Issler O, Ezra-Nevo G, Gil S, Zwang R, Hornstein E \& Chen A 2011 MicroRNA as repressors of stress-induced anxiety: the case of amygdalar miR-34. Journal of Neuroscience 31 14191-14203. (doi:10.1523/JNEUROSCI.1673-11.2011)

Huising MO, van der Meulen T, Vaughan JM, Matsumoto M, Donaldson CJ, Park H, Billestrup N \& Vale WW 2010 CRFR1 is expressed on pancreatic beta cells, promotes beta cell proliferation, and potentiates insulin secretion in a glucose-dependent manner. PNAS 107 912-917. (doi:10.1073/pnas.0913610107)

Javelle M \& Timmermans MC 2012 In situ localization of small RNAs in plants by using LNA probes. Nature Protocols 7 533-541. (doi:10.1038/ nprot.2012.006)

Kang L, Cui XX, Zhang YJ, Yang CH \& Jiang YL 2013 Identification of miRNAs associated with sexual maturity in chicken ovary by Illumina small RNA deep sequencing. BMC Genomics 14352. (doi:10.1186/1471-2164-14-352) 
Karalis K, Sano H, Redwine J, Listwak S, Wilder RL \& Chrousos GP 1991 Autocrine or paracrine inflammatory actions of corticotropinreleasing hormone in vivo. Science 254 421-423. (doi:10.1126/ science.1925600)

Kiapekou E, Zapanti E, Voukelatou D, Mavreli T, Stefanidis K, Drakakis P, Mastorakos G \& Loutradis D 2011 Corticotropin-releasing hormone inhibits in vitro oocyte maturation in mice. Fertility and Sterility 95 1497-1499.e1491. (doi:10.1016/j.fertnstert.2010.12.023)

Kovalovsky D, Refojo D, Liberman A, Hochbaum D, Pereda M, Coso O, Stalla G, Holsboer F \& Arzt E 2002 Activation and induction of NUR77/ NURR1 in corticotrophs by CRH/cAMP: involvement of calcium, protein kinase A, and MAPK pathways. Molecular Endocrinology 16 1638-1651. (doi:10.1210/mend.16.7.0863)

Landgraf P, Rusu M, Sheridan R, Sewer A, lovino N, Aravin A, Pfeffer S, Rice A, Kamphorst AO, Landthaler M et al. 2007 A mammalian microRNA expression atlas based on small RNA library sequencing. Cell 129 1401-1414. (doi:10.1016/j.cell.2007.04.040)

Li Y, Pan J, Wei C, Chen J, Liu Y, Liu J, Zhang X, Evans SM, Cui Y \& Cui S 2014 LIM homeodomain transcription factor Isl1 directs normal pyloric development by targeting Gata3. BMC Biology 1225. (doi:10.1186/1741-7007-12-25)

Makrigiannakis A, Margioris AN, Le Goascogne C, Zoumakis E, Nikas G, Stournaras C, Psychoyos A \& Gravanis A 1995 Corticotropinreleasing hormone $(\mathrm{CRH})$ is expressed at the implantation sites of early pregnant rat uterus. Life Science 57 1869-1875. (doi:10.1016/00243205(95)02167-H)

Mastorakos G, Webster EL, Friedman TC \& Chrousos GP 1993 Immunoreactive corticotropin-releasing hormone and its binding sites in the rat ovary. Journal of Clinical Investigation 92 961-968. (doi:10.1172/ JCI116672)

Nemoto T, Mano A \& Shibasaki T 2013 miR-449a contributes to glucocorticoid-induced CRF-R1 downregulation in the pituitary during stress. Molecular Endocrinology 27 1593-1602. (doi:10.1210/ me.2012-1357)

Nothnick WB 2012 The role of micro-RNAs in the female reproductive tract. Reproduction 143 559-576. (doi:10.1530/REP-11-0240)

Park HJ, Kim H, Lee J, Lee J, Cho B, Kang J, Kang H, Yang Y \& Choz D 2005 Corticotropin-releasing hormone $(\mathrm{CRH})$ downregulates interleukin-18 expression in human HaCaT keratinocytes by activation of p38 mitogenactivated protein kinase (MAPK) pathway. Journal of Investigative Dermatology 124 751-755. (doi:10.1111/j.0022-202X.2005.23656.x)

Polkowska J \& Przekop F 1997 The effect of corticotropin-releasing factor (CRF) on the gonadotropin hormone releasing hormone $(\mathrm{GnRH})$ hypothalamic neuronal system during preovulatory period in the ewe. Acta Neurobiologiae Experimentalis 57 91-99.

Salak-Johnson JL, Anderson DL \& McGlone JJ 2004 Differential dose effects of central CRF and effects of CRF astressin on pig behavior. Physiology and Behavior 83 143-150. (doi:10.1016/j.physbeh.2004.08.005)

Sen A, Prizant H, Light A, Biswas A, Hayes E, Lee HJ, Barad D, Gleicher N \& Hammes SR 2014 Androgens regulate ovarian follicular development by increasing follicle stimulating hormone receptor and microRNA-125b expression. PNAS 111 3008-3013. (doi:10.1073/pnas.1318978111)

Shen X, Park JS, Qiu Y, Sugar J \& Yue BY 2009 Effects of Sp1 overexpression on cultured human corneal stromal cells. Genes to Cells 14 1133-1139. (doi:10.1111/j.1365-2443.2009.01340.x)

Sirotkin AV, Ovcharenko D, Grossmann R, Laukova M \& Mlyncek M 2009 Identification of microRNAs controlling human ovarian cell steroidogenesis via a genome-scale screen. Journal of Cellular Physiology 219 415-420. (doi:10.1002/jcp.21689)

Sirotkin AV, Laukova M, Ovcharenko D, Brenaut P \& Mlyncek M 2010 Identification of microRNAs controlling human ovarian cell proliferation and apoptosis. Journal of Cellular Physiology 223 49-56. (doi:10.1002/ jcp.21999)

Spiess J, Dautzenberg F, Sydow S, Hauger R, Rühmann A, Blank T \& Jelena R 1998 Molecular properties of the CRF receptor. TEM 9 140-145. (doi:10.1016/s1043-2760(98)00037-x)

Stengel A \& Tache Y 2014 CRF and urocortin peptides as modulators of energy balance and feeding behavior during stress. Frontiers in Neuroscience 8 52. (doi:10.3389/fnins.2014.00052)

Ulisse S, Fabbri A \& Dufau ML 1989 Corticotropin-releasing factor receptors and actions in rat Leydig cells. Journal of Biological Chemistry $2642156-2163$.

Wang F, Li Y, Zhou J, Xu J, Peng C, Ye F, Shen Y, Lu W, Wan X \& Xie X 2011 miR-375 is down-regulated in squamous cervical cancer and inhibits cell migration and invasion via targeting transcription factor SP1. American Journal of Pathology 179 2580-2588. (doi:10.1016/j. ajpath.2011.07.037)

Xu S, Linher-Melville K, Yang BB, Wu D \& Li J 2011 Micro-RNA378 (miR378) regulates ovarian estradiol production by targeting aromatase. Endocrinology 152 3941-3951. (doi:10.1210/en.2011-1147)

Yoon DJ, Sklar C \& David R 1988 Presence of immunoreactive corticotropin-releasing factor in rat testis. Endocrinology 122 759-761. (doi:10.1210/endo-122-2-759)

Zhang N, Lin JK, Chen J, Liu XF, Liu JL, Luo HS, Li YQ \& Cui S 2013 MicroRNA 375 mediates the signaling pathway of corticotropin-releasing factor (CRF) regulating pro-opiomelanocortin (POMC) expression by targeting mitogen-activated protein kinase 8. Journal of Biological Chemistry 288 10361-10373. (doi:10.1074/jbc.M112.425504)

Zoumakis E, Makrigiannakis A, Margioris A, Stournaras C \& Gravanis A 1996 Corticotropin releasing hormone $(\mathrm{CRH})$ in normal and pregnant uterus: physiological implications. Frontiers in Bioscience $\mathbf{1}$ e1-e8. (doi:10.2741/A137)

Received 15 June 2016

First decision 11 July 2016

Revised manuscript received 1 October 2016

Accepted 18 October 2016 